Journal of Educational Method and Technology Vol. 2 No. 3, Desember 2019

P-ISSN 2622-8459 E-ISSN 2622-8467

http://ejournal.unima.ac.id/index.php/jemtec

\title{
Interpreting Metaphor In Sidney Mohede's Song Lyrics
}

\author{
F B Sumigar ${ }^{1}$, M G Maru², I J C Tuerah ${ }^{3}$ \\ 1,2,3 Universitas Negeri Manado, Indonesia \\ corresponding author: ${ }^{1}$ mrgidionmaru@unima.ac.id
}

\begin{abstract}
This research aimed at describing the metaphors used by the Mohede in the eight songs he wrote. As a qualitative research, this study rellied the data upon the lyrics of the chosen songs. The analysis applies theory of Lakoff and Johnson which divided metaphors into three types namely structural metaphor, orientational metaphor, and ontological metaphor. The analysis followed the steps of Bogdan and Biklen as follows identification, categorization, explanation, and interpretations of the findings. The result showed that the songs confirmed the existence the types of the metaphors such as structural metaphor, orientational metaphor and ontological metaphor. These findings implies a pivotal contribution of figurative speech particularly metaphor in communicating the meaning of a song. Thus, this study foreshadows a further research for comprehending the relationship of metaphor to song lyrics for both linguistic and literary context.
\end{abstract}

Keywords: mathematical ability; students; Problem-Based Learning.

\section{Introduction}

One of the media for communication is a song. Similar to a poem, a song apllies figurative languages. It is a language expression, whose meaning is different from its literal one, It drives listeners to spend extra effort to understand the meaning of a song. It is a composition of voice performed by a singer or by a musical instrument. There are many messages delivered in a song. According to the Grolier, "Song is a short musical work set a poetic text with equal importance given to music and to the words. Most of the lyrics of the songs are full of meanings". The meanings of the songs are not merely interpreted by the words written literally, but the words written in the lyric have other meanings and even deeper meaning if they are interpreted and internalized well. That means that the power of song is not only in the rythm but also in the langauge used in the lyrics.

People listen to song for their own purposes. Hornby (1974:822) stated that song lyric is a short poem in a number of verses set to music to be sung. In its writing, the songwriters or composers usually beautify the language they use by any metaphor so that the listeners will be more attracted in listening to the song. The 
metaphors seem to bridge the effort of the song writer to actualize his feeling and purpose. This study addresses the issue of the contribution of metaphors in the songs of the gospel songwriter, Sidney Mohede, The songs are Rest In You, You Are My Hiding Place, and Lord I Surrender. These songs are regarded being the most prominent and popular song composed amd sung by Sidney Mohede. It brings the assumption that the songs are successful in communicating their religious message and reaches audience of distinct social levels. That indicates that it deserves to be studied in terms of seeing the function of figurative language particularly metaphor in communicating ideas in the specific context; religious one.

\section{Research Methods}

This study is qualitative one. The data collected are in the form of words or picture rather than number. The lyrics serve as data to be analyzed. By following Bogdan and Biklen steps for analysis namely identification, categorization, explanation, and interpretations, the analysis also based upon theory metaphors as proposed by Lakoff and Johnson.

\section{Result and Discussion}

The analysis on the lyrics of Mohede's songs result on the findings that each song has metaphors within them. The metaphor are distributed and used as following categorization.

\section{Structural Metaphor}

This metaphor is a conventional metaphor in which one concept is understood and expressed in terms of another structure. The characteristics of structural metaphor as follow (Lakoff and Johnson, 1980:4-5, 61):

a. Operate as a guide to meaning and action in the discursive context within it operates.

b. Explain or illustrate the concept of abstraction to concrete concept as typical word which is linked to it.

The following expressions (shown by bolded words) are categorized as a structural metaphor as indicated by Lakoff and Johnson:

- Find me in the desert (Verse 1, line into-1)

- Find me here in the water (Verse 2, line into-1)

- You formed me (Verse 1, line into-3)

- Turn my darkness into dawn (Verse 2, line into-6)

- A spring in every winter (Verse 1, line into-4)

- Through every season You are near (Verse 1, line into-6)

- You lift me when I fall (Verse 2, line into-3b)

\section{Orientational Metaphor}

An orientational metaphor is a metaphor in which concepts arespatially related to each other, as in the following ways:

a. up or down,

b. in or out,

c. front or back, 
Journal of Educational Method and Technology Vol. 2 No. 3, Desember 2019

P-ISSN 2622-8459 E-ISSN 2622-8467

http://ejournal.unima.ac.id/index.php/jemtec

d. on or off,

e. deep or shallow,

f. central or peripheral,

g. health and life are up,

h. sickness and death and,

i. More is up and less is down (Lakoff and Johnson, 1980:14 - 15, 18).

In this part can be seen that the singer/ poet (s) uses some words and expressions indicating orientational metaphor as follows (shown by the bolded words):

- You can hush the raging storms (Verse 1, line into-2)

- You hear my every cry (Verse 1, line into-8)

- I'm covered by Your grace (Verse 2, line into-4)

- By Your blood death has lost (Verse 2, line into-7)

- You took the cross (Verse 1, line into-1)

- It is done by Your blood (Chorus, line into 1)

- Your death has brought the dead to life (Verse 2, line into-5)

\section{Ontological Metaphor}

This Ontological metaphor refers to a metaphor in which abstraction as mentioned by Lakoff and Johnson (1980:25 - 33). The ontological metaphor includes an object, things, substance, and container or person. Sidney and the other poets experienced the mercies of God. They praised their God through songs of praise and thanksgiving prayers to rewarding all blessings and protections of God. The emotion prayers and poem of the praise songs are given as a kind of true worship. Some words and expression are found in some lyrics in Sidney song as an ontological metaphor is shown (in bolded words) below:

- Just wondering on this path (Verse 1, line into-2)

- In Your presence (Verse 1, line into-4)

- The place where You are (Chorus, line into-1)

- Deep inside Your heart (Chorus, line into-4b)

- You can breathe all the stars (Verse 1, line into-1)

- You are my hiding place (Chorus, line into-7)

- That I may dwell in the house of my king (Verse 2, line into 2)

- Where can I go from Your Spirit (Verse 2, line into 1)

- Where can I go from Your presence (Verse 2, line into 2)

- Light the world and salt the earth (Chorus, line into-3) 
Journal of Educational Method and Technology Vol. 2 No. 3, Desember 2019

P-ISSN 2622-8459 E-ISSN 2622-8467

http://ejournal.unima.ac.id/index.php/jemtec

\begin{tabular}{|c|c|c|c|}
\hline \multirow[t]{2}{*}{ No } & \multicolumn{3}{|c|}{$\begin{array}{c}\text { Types of Metaphors } \\
\text { (Lakoff and Johnson; 1980) }\end{array}$} \\
\hline & Structural Metaphor & Orientational Metaphor & Ontological Metaphor \\
\hline 1 & $\begin{array}{l}\text { desert } \\
\text { (Verse } 1, \text { line into- } 1 \text { ) }\end{array}$ & $\begin{array}{l}\text { hush the raging storms } \\
\text { (Verse } 1 \text {, line into- } 2 \text { ) }\end{array}$ & $\begin{array}{l}\text { wondering } \\
\text { (Verse } 1 \text {, line into-2) }\end{array}$ \\
\hline 2 & $\begin{array}{l}\text { water } \\
\text { (Verse 2, line into-1) }\end{array}$ & $\begin{array}{l}\text { Cry } \\
\text { (Verse 1, line into-8) }\end{array}$ & $\begin{array}{l}\text { In Your presence } \\
\text { (Verse 1, line into-4) }\end{array}$ \\
\hline 3 & $\begin{array}{l}\text { formed me } \\
\text { (Verse } 1, \text { line into-3) }\end{array}$ & $\begin{array}{l}\text { Covered } \\
\text { (Verse } 2, \text { line into-4) }\end{array}$ & $\begin{array}{l}\text { the place where You are } \\
\text { (Chorus, line into-1) }\end{array}$ \\
\hline 4 & $\begin{array}{l}\text { darkness, dawn } \\
\text { (Verse 2, line into-6) }\end{array}$ & $\begin{array}{l}\text { Lost } \\
\text { (Verse 2, line into-7) }\end{array}$ & $\begin{array}{l}\text { Your heart } \\
\text { (Chorus, line into- } 4 \mathrm{~b})\end{array}$ \\
\hline 5 & $\begin{array}{l}\text { a spring, winter } \\
\text { (Verse } 1, \text { line into- } 4 \text { ) }\end{array}$ & $\begin{array}{l}\text { You took the cross } \\
\text { (Verse } 1, \text { line into- } 1 \text { ) }\end{array}$ & $\begin{array}{l}\text { breathe all the stars } \\
\text { (Verse } 1 \text {, line into- } 1 \text { ) }\end{array}$ \\
\hline 6 & $\begin{array}{l}\text { every season } \\
\text { (Verse } 1 \text {, line into-6) }\end{array}$ & $\begin{array}{l}\text { done by Your blood } \\
\text { (Chorus, line into } 1 \text { ) }\end{array}$ & $\begin{array}{l}\text { hiding place } \\
\text { (Chorus, line into-7) }\end{array}$ \\
\hline 7 & $\begin{array}{l}\text { lift, fall } \\
\text { (Verse } 2 \text {, line into- } 3 b \text { ) }\end{array}$ & $\begin{array}{l}\text { the dead to life } \\
\text { (Verse 2, line into-5) }\end{array}$ & $\begin{array}{l}\text { dwell in the house } \\
\text { (Verse 2, line into 2) }\end{array}$ \\
\hline 8 & & & $\begin{array}{l}\text { Your Spirit } \\
\text { (Verse 2, line into 1) }\end{array}$ \\
\hline 9 & & & $\begin{array}{l}\text { Your presence } \\
\text { (Verse } 2 \text {, line into } 2 \text { ) }\end{array}$ \\
\hline 10 & & & $\begin{array}{l}\text { Light, salt } \\
\text { (Chorus, line into-3) }\end{array}$ \\
\hline
\end{tabular}

\section{Discussion}

\section{a. Structural Metaphor}

1) Find me here in the desert (Verse 1, line into-1)

The lyrics Find me here in the desert in Verse 1, line into-1contain a metaphor and the word desert is a metaphor contained in the lyrics. The word desert can be categorized in structural metaphors because it has the connotative meaning to operate something. This word tries to explain the abstract concept of the desert in this world where humans live, and it is on its way. He did not know which way to take and he was looking for a way to get out of the desert. It shows metaphorically making in the lyrics of his song that invites hope with God finding himself, then God will guide him to get a solution in the midst of problems and difficulties he faces with the concrete concept of the desert as a typical word which linked to it.

2) Find me herein the water (Verse 2, line into-1)

Find me here inthe water is a structural metaphor because in indirect communication the speaker in his song where he wants to tell people that the human being is limited. The author describes himself as lost or lost in a vast ocean or ocean. He was losing direction and purpose in his life and did not 
Journal of Educational Method and Technology Vol. 2 No. 3, Desember 2019

P-ISSN 2622-8459 E-ISSN 2622-8467

http://ejournal.unima.ac.id/index.php/jemtec

know where to go. He really needed God's help for his life that was lost. In the vast ocean it is very difficult for humans to find it, it might not even be found, but God will definitely find and save it. This is a concept of the poet to tell the power of God in another way in his to the song. This form tries to explain the abstract concept of how to watch with the concrete concept of find me here in the water as typical words or phrase which linked to it.

3) Yet You formed me (Verse 1, line into-3)

You formed me is a structural metaphor because in indirect communication the poet in his song where he wants to tell the people that the human being is created by God. The poet, in this case, describes the omnipotence of God, where God has the power to make everything from nothing to being, including human beings. This is a concept of the poet to tell the power of God in another way in his to the song. This form tries to explain the abstract concept of how to watch with the concrete concept ofYou formed me as typical words or phrase which linked to it.

4) Could turn my darkness into dawn (Verse 2, line into-6)

The words of could turn my darkness into dawn are a structural metaphor. Because these words try to explain the abstract concept the replacing darkness into dawn with the concrete concept of hope and future as typical words which are linked to it. The poet revealed that God in His omnipotence was able to turn death into life and turn difficulties or problems into blessings and despair into hope.

5) There is a spring in every winter (Verse 1, line into-4)

This phrase indicates a structural metaphor because the poet has related means. Spring in every winter this phrase is chosen by the poet to tell the people about a human condition that God is able to provide a beautiful future, where the future really exists and hope will never be lost in God. This phrase tries to explain the abstract concept of spring in every winter with the concrete concept of a new season or future and as typical words or phrase which linked to it.

6) Through every season You are near (Verse 1, line into-6)

The word of every season is a connotative form of Condition or situation. Every season in this verse is categorized in structural metaphor because this word tries to replace the abstract concept, the condition or situation of the with setting down the concrete concept of every season as typical words which linked to it. The poet states a condition which places God as the regulator of everything in his life. Where the author states about God's concern, where God is always present in all times, situations and circumstances experienced by humans.

7) You wipe away the tears, you lift me when I fall

The word of you lift me when I fall is a structural metaphor. Because these words try to explain the abstract concept to restore and giving hope with the concrete concept of you lift me when I fall as typical words which are linked to it. The poet in his song gives a very beautiful picture of God's wonderful goodness, the poet expresses that only God gives true and complete freedom and victory in this life that is even capable of turning every difficulty and difficulty into joy and even giving recovery and hope in human life. 
Journal of Educational Method and Technology Vol. 2 No. 3, Desember 2019

P-ISSN 2622-8459 E-ISSN 2622-8467

http://ejournal.unima.ac.id/index.php/jemtec

\section{b. Orientational Metaphor}

1) You can hush the raging storms (Verse 1, line into-2)

This clause is categorized into an orientational metaphor. Because this form is cited to illustrate the concept of Peace and still is UP. You can hush the raging storms explained how God has the power to provide peace in human life when facing problems in his life. There is no problem that cannot be solved by God as ruler of the universe. In addition, the singer also illustrates that everything under the heavens will be subject to His power.

2) And You hearmy every cry (Verse 1, line into-8)

You hear my every cry is an orientational metaphor because this word is cited to illustrate the concept of sadness and mourning are DOWN. every cry it is also a condition of human beings who are in a situation of falling, falling and carrying a great burden and suffering as a result of their sins and weaknesses. In this case God as an omniscient God by the author believes that God can turn every suffering, and weeping into joy and can solve every problem encountered.

3) I'm covered by Your grace (Verse 2, line into-4)

The word covered is classified into orientation metaphors. Because this phrase is quoted to replace the protected concept is UP. This illustrates how God's love for human beings is illustrated and this form shows His grace.The singer is also describing human life, which is a condition in which humans actually get something very valuable in their lives that human beings actually have no right to get.

4) By Your blood death has lost (Verse 2, line into-7)

The phrase by Your blood death has lost is classified to orientational metaphor. Because this phrase is cited to substitute the concept of Your Blood is UP. Your blood is illustrated how God with his blood or sacrifice, has overcome sin and the power of eternal death in humans. with the sacrifice of the Lord Jesus, for people who believe in Jesus will have eternal life and freedom. Even though humans will experience death but will experience life again.

5) You took the cross (Verse 1, line into-1)

The phrase of You took the cross is an orientational metaphor because this phrase is cited to substitute the concept of sickness and death are DOWN. Took the cross is explained by the salvation of the man. In another illustration, it gives an amazing picture where the Lord Jesus has lifted our burdens and sins and sufferings with the intention that every believer will experience peace and rest in his life.

6) It is done, it is done by Your blood (Chorus, line into 1)

The phrase it is done by Your blood is an orientational metaphor because this phrase is cited to substitute the concept of sickness and death are DOWN. it is done by Your blood is explained by the eternity live of the man. Humans are actually full of sins and mistakes and deserved to be punished for violations, but by His blood all conditions have been resolved by God, so humans have freedom and salvation in their lives.

7) Your death has brought the dead to life (Verse 2, line into-5) 
Journal of Educational Method and Technology Vol. 2 No. 3, Desember 2019

P-ISSN 2622-8459 E-ISSN 2622-8467

http://ejournal.unima.ac.id/index.php/jemtec

The phrase Your death has brought the dead to life is an orientational metaphor because this phrase is cited to substitute the concept of weakness and death are DOWN. Your death has brought the dead to life is explained by the salvation from God where eternal death becomes eternal life for humans. This is a picture of God having power over life and death where this power is only possessed by God himself, which is seen how God turns death into life.

\section{c. Ontological Metaphor}

1) Just wondering on this path (Verse 1, line into-2)

The word wondering in this verse is the ontological metaphor. Because it illustrates the concept of feel surprise or amazement. This admiration occurs because of a spiritual experience of how God provides guidance and guidance and the right direction in the journey of human life so that from the guidance there is a success, so that an admiration for the way God in his guidance. It is represented to show that God's work in guiding his people and illustrate to a concrete thing as typical words which linked to it.

2) In Your presence I'll be found (Verse 1, line into-4)

This phrase is an ontological metaphor because illustrate the shelter and this is represented as something concrete as an object or things. In Your presence represents a concrete thing of shelter.God's Presence describes a place or condition where humans will experience a calm atmosphere or condition in their lives even though they face various difficulties and problems in their lives.

3) And I will run to the place where You are (Chorus, line into-1)

This phrase is an ontological metaphor because illustrate the shelter and this is represented as something concrete as an object or things. The place where you are represents a concrete thing of shelter.This shows the only place where humans can find peace and even hope for humans. a place where someone feels accepted, loved, loved and even experiences inner peace.

4) With open arms You bring me deep inside Your heart (Chorus, line into-4b) This phrase is an ontological metaphor because illustrate the love or acceptance and this is represented as something concrete as an object or things. Deep inside Your heart represents a concrete thing of love.Love that is described unlimitedly, a picture of extraordinary acceptance in humans. Humans are full of transgressions, sins and mistakes but all those violations and sins are not counted by God. In his great love we are loved and accepted as we are by God.

5) You can breathe all the stars (Verse 1, line into-1)

This phrase illustrates the concept of God's power gives life with the concrete concept of breathe. It is represented to produce the good thing and illustrate to a concrete thing as typical words which are linked to it, so that's why it is classified into the ontological metaphor. The singer describes through his poetry that God is in charge of the universe where God created the celestial body and placed it in such a way as to declare the glory of his omnipotence. In this case mortal men will worship the eternal God.

6) You are my hiding place (Chorus, line into-7) 
Journal of Educational Method and Technology Vol. 2 No. 3, Desember 2019

P-ISSN 2622-8459 E-ISSN 2622-8467

http://ejournal.unima.ac.id/index.php/jemtec

This form explains the abstraction of word protection and the harborage of The Almighty God with a concrete concept of the hiding place. Those are illustrating an object to give a metaphorical form to euphemize the divinity of God, so that's why it is classified into an ontological metaphor. Hiding place provides a picture of God as a person who is a safe haven and as a person who is fully responsible for the safety of those who take refuge in God.

7) That I may dwell in the house of my king (Verse 2, line into-2)

This phrase is an ontological metaphor because illustrate the shelter and this is represented as something concrete as an object or things. Dwell in the house represents a concrete thing of shelter.In addition, dwell in the house provides a description of the conditions or circumstances in which humans get guarantees and supplies for all their needs in life.

8) where can I go from Your Spirit (Verse 2, line into-1)

This word illustrates the concept of the person of God with a concrete concept. It represents the spirit and illustrate to a concrete thing as typical words which are linked to it, so that's why it is classified into the ontological metaphor. In addition, this also illustrates that no human can hide from God, all human efforts to hide themselves will never be possible because God is all-knowing. So that in His omnipotence, not a single human can hide before Him.

9) Where can I go from Your presence (Verse 2, line into-2)

This phrase is an ontological metaphor because illustrate the shelter and this is represented as something concrete as an object or things. In Your presence represents a concrete thing of shelter.Presence it also illustrates that God can be present anywhere so that there is no place for humans to hide. God who is present will always know every trace of our steps, and every action we do. Even if people try to distance themselves from God's presence, they will experience a very sad state of life.

10) light the world salt the earth

This phrase illustrates the concept of always doing righteousness with a concrete concept of light and salt. It is represented to produce the good thing and illustrate to a concrete thing as typical words which are linked to it, so that's why it is classified into ontological metaphor.

Thus, Based on Lakoff and Johnson's theory of the types of metaphors, it can be synthesized that there are twenty four lines containing metaphors consist of seven structural metaphors, seven orientational metaphors, and ten ontological metaphors. This indicates that the use of metaphor helps the song writer to communicate his feeling anf thoughts, even his religiousity. The use of metaphors have facilitated the devotional expression and feeling. They illustrate the admiration and acknowledgment of God's existence and greatness. The metaphors strenthen the effort to communicate the meaning of the song for both vertical; to God; and horizontal; to listeners. In this stage, the metaphor functions as the media for interaction and communication for religious and social context. It expresses the attempt to communicate with different audience at same time. Hence, it reflects the function of figurative language in communication scheme. 
Journal of Educational Method and Technology Vol. 2 No. 3, Desember 2019

P-ISSN 2622-8459 E-ISSN 2622-8467

http://ejournal.unima.ac.id/index.php/jemtec

\section{Conclusion}

Having accomplished the research, it can be concluded that in Sidney Mohede's song lyrics contain metaphorical expressions in the form of words, phrases and also clauses. Basing upon the theory of Lakoff and Johnson, the metaphors come in the forms of structural metaphor, orientational metaphor, and ontological metaphor. The result of the research showed that the songwriter involved twenty-four metaphor expressions in his eight songs. This use of metaphors suggests the role of metaphor in the lyrics of a song. It functions to convey both spiritual and social meanings. A metaphor energizes the linguistic and religious nuance of a song.

\section{References}

Bogdan and Biklen. 1992. Qualitative Research for Education; An Introduction to Theory and Methods, second edition. Massachusetts: Allyn and Bacon inc.

Bonvillain, N. 1997. Language, Culture and Communication; The Meaning of Messages. New Jersey. Prentice Hall inc.

Chatman, S. 1968. An introduction to the language of poetry.Boston:Hougton Mifflin Company

Crystal, D. 1992. The Cambridge Encyclopedia of Language. New York. Cambridge University Press

Griffee. Dale T. 1992.Songs in Action. Prentice Hall International (UK) Ltd Hall,

Hornby, A. S. 1995. Oxford Advanced Learner's Dictionary.Oxford University Press.NewYork.

Keraf, Gorys. 1997. KomposisiSebuahPengantar Kemahiran Bahasa.Ende Flores. Nusa Indah.

Klarer, Mario. 2004. An Introduction to Literary Studies Second Edition. New York: Roudledge.

Korte, Barbara, et al. 1997. Einführung in dieAnglistik. Stuttgart. Weimar-Metzier

Kreidler, Charles W. 1998. Introducing English Semantics.Routledge 11 New Fetter Lane, London

Lakoff G and Johnson M, 1980. Metaphors We Live. Chicago, The University of Chicago Press Ltd.

Lakoff, G and Mark, J. 2003. Metaphor we live by. London: The University of Chicago Press.

Liando, N.V.F and Lumettu, R. 2017. Student's Personal Initiative towards their Speaking Performance. International Education Studies, vol. 5, no.8; 2017.

Maru, Mister G. et al. 2016. A Discourse Analysis of Figurative Language in Barack Obama's Speech. Journal Vol.1, no.1 November 2016

Ministry, Y. 2012. Available http://sidneymohede.com/.

Nazir M. 1998. MetodePenelitian. Jakarta. Ghalia Indonesia.

Parera, Jos Daniel. 2004. TeoriSemantik. Erlangga. Jakarta.

Pei Mario A. and Gaynor F. 1980. A Dictionary of Linguistics. New Jersey. Littlefield, Adams and co.

Tuerah, C.I, Javier dkk. 2018. Study of English Language Spelling. Advances in Social Science, Education and Humanities Research, volume 226 
Journal of Educational Method and Technology Vol. 2 No. 3, Desember 2019

P-ISSN 2622-8459 E-ISSN 2622-8467

http://ejournal.unima.ac.id/index.php/jemtec

Tuerah C. J, Ignatius. Tuilan, Jeane. Rakian, Sandra. 2017. Syntactical Error on Students' Descriptive Composition. JELLT, VOL 2, NO 2 Desember 2017 printed ISSN: 2548-7728 E- ISSN: 2599-0373

Wilden, A. 1987. The rules are not game: The strategy of communication. London: Routledge.

Yule, G. 1996. Pragmatics. Oxford. Oxford University Press 